\title{
Antihyperglycemic Effect of Cephalotaxus sinensis Leaves and GLUT-4 Translocation Facilitating Activity of Its Flavonoid Constituents
}

\author{
Wei LI, ${ }^{a, b}$ Rong-Ji DAI, ${ }^{a, b}$ Yu-Hong YU, ${ }^{*, a, b}$ Liang LI, ${ }^{a, b}$ Chong-Ming Wu, ${ }^{a}$ Wei-Wei Luan, ${ }^{a}$ \\ Wei-Wei Meng, ${ }^{a, b}$ Xin-Sheng ZHANG, ${ }^{b}$ and Yu-Lin DenG*,a \\ ${ }^{a}$ School of Life Science and Technology, Beijing Institute of Technology; Beijing 100081, P. R. China: and ${ }^{b}$ Beijing BIT \& \\ GY Pharmaceutical R\&D; Beijing 100081, P. R. China. Received November 3, 2006; accepted February 16, 2007
}

\begin{abstract}
The objectives of this study were to investigate the antihyperglycemic effect of Cephalotaxus sinensis leaves and to identify the active components. The antihyperglycemic effect of various fractions (FA, FB, FC, FD) of the $80 \%$ ethanol extract of the leaves was evaluated in streptozotocin (STZ)-induced diabetic rats. Among the tested fractions, FC was the most active. FC $(0.48 \mathrm{~g} / \mathrm{kg})$ given orally for $10 \mathrm{~d}$ reduced significantly $(p<0.001)$ the blood glucose of STZ-induced diabetic rats. The food and water intakes of FC $(0.48 \mathrm{~g} / \mathrm{kg})$-treated diabetic rats were reduced significantly $(p<0.001)$ when compared to the $0.5 \%$ carboxymethyl cellulose (CMC)-treated diabetic rats. The activity-guided fractionation of the ethanol extract of $C$. sinensis leaves furnished three flavonoid compounds, apigenin-5- $O$-[ $\alpha$-L-rhamnopyranosyl- $(1 \rightarrow 4)-6-O-\beta$-D-acetylglucopyranoside $](1)$, apigenin $(2)$, and apigenin-5- $O$ - $[\alpha$-L-rhamnopyranosyl- $(1 \rightarrow 4)-6-O-\beta$-D-glucopyranoside] (3). The elevation of GLUT-4 protein level in membrane preparations from mice adipocytes was detected by Western blot analysis after adipocytes were preincubated with FC $(0.1,1,10 \mathrm{mg} / \mathrm{ml})$, apigenin $(0.1,2 \mathrm{mg} / \mathrm{ml})$ and apigenin-5- $O$-[ $\alpha$-L-rhamnopyranosyl- $(1 \rightarrow 4)-6-$ $O$ - $\beta$-D-acetylglucopyranoside] $(0.1,2 \mathrm{mg} / \mathrm{ml})$, respectively. Phytochemical investigation and HPLC-DAD analysis of $\mathrm{FC}$ indicated that the flavonoids were the major constituents in this fraction. These results suggest that the fraction from $C$. sinensis leaves is a promising drug for the treatment of diabetes, and that the flavonoids from this plant are the active constituents.
\end{abstract}

Key words Cephalotaxus sinensis; antihyperglycemic effect; GLUT-4; translocation; apigenin; HPLC-DAD

Type 1 diabetes and type 2 diabetes (T2D) rank highly among the top 10 causes of mortality throughout the world. Diabetes patients, particularly those with $\mathrm{T} 2 \mathrm{D}$ are at considerable risk of excessive morbidity and mortality from cardiovascular, cerebrovascular, and peripheral vascular diseases leading to myocardial infarction, strokes, and amputations. ${ }^{1)}$

With the rapid advancements in medicine, novel treatments with fewer side effects have become feasible for the long-term control of this disorder. Recent scientific investigation has confirmed the efficacy of many of plant medicines on diabetes mellitus (DM), some of which are remarkably effective. $^{2)}$ The recommendation of the WHO committee on DM encouraged research on hypoglycemic agents of plant origin used in Chinese traditional medicine and it has greatly motivated research in this area. ${ }^{3)}$

Insulin-stimulated glucose utilization is the major site for regulation of plasma glucose concentrations. ${ }^{4)}$ Glucose transport is the rate-limiting step in carbohydrate metabolism. ${ }^{5)} \mathrm{A}$ family of glucose transporters (GLUT) mediates glucose transport across the cell membrane, and the subtype 4 form (GLUT-4) is the insulin sensitive glucose transporter. Reduction in insulin-mediated glucose uptake caused by decreasing GLUT-4 protein in diabetes, especially T2D, was observed. ${ }^{6,7)}$ Compounds that facilitate GLUT-4 translocation can be potentially beneficial for the treatment of diabetes, especially for T2D.

Cephalotaxus sinensis (ReHD et WILE) LI, a medicinal plant and widely distributed in southern China, has been used as a Chinese traditional medicine for treatment of dyspepsia, ascariasis, inflammation, and cough. ${ }^{8)}$ Alkaloids, flavonoids, biflavonoids, and diterpenes were reported to be constituents of Cephalotaxus species. ${ }^{9-11)}$ It was reported that the ester type alkaloids possessed antitumour activity. ${ }^{8)}$ Recently, osteoblast differentiation stimulating activity of bi- flavonoids from Cephalotaxus koreana NAKAI (Cephalotaxaceae) have been reported. ${ }^{12)}$

To the best of our knowledge, there are no reports on the antihyperglycemic activity of $C$. sinensis in the literature. As part of a series of experiments to obtain natural products with antidiabetic efficacy from plants, the antihyperglycemic activity of various fractions of the ethanol extract of $C$. sinensis leaves were evaluated in chronic STZ-induced diabetic rats. The activity of the isolated compounds from the fraction was estimated at the cellular level in vitro. The study elucidated for the first time the biologic properties, namely the activity of facilitating GLUT-4 translocation, of the fraction and its flavonoid constituents from $C$. sinensis. Furthermore, we characterized the main components of the fraction by using phytochemical and HPLC-DAD methods.

\section{MATERIALS AND METHODS}

Plant Material The leaves of $C$. sinensis were collected from Liangtian, Dongzhi, Anhui province, P. R. China, in May 2003. The plant was identified by Dr. Sheng-Yuan Xiao (School of Life Science and Technology, Beijing Institute of Technology, Beijing, P. R. China) and Associate Researcher Bin Wen (Xishuangbanna Tropical Botanical Garden, Chinese Academy of Sciences, P. R. China), and a voucher specimen (No. S200305) has been deposited in the lab of the School of Life Science and Technology, Beijing Institute of Technology.

HPLC-DAD Conditions An Elite P230 series HPLCDAD system consisting of a binary pump and a DAD detector (Elite DAD230, P. R. China) was used for acquiring chromatograms and UV spectra. The HPLC condition was as follows: column, Diamonsil ${ }^{\mathrm{TM}} \mathrm{C}_{18}$ column $(5 \mu \mathrm{m}, 250 \times 4.6 \mathrm{~mm}$, Dikama, P. R. China ); column temperature, $25^{\circ} \mathrm{C}$; mobile 
phases: linear gradient system of solvent $\mathrm{A}\left(\mathrm{H}_{2} \mathrm{O}+0.1 \%\right.$ acetic acid) and solvent $\mathrm{B}$ (acetonitrile), B/A 10/90 (0 min), $15 / 85$ (10 $\mathrm{min}), 30 / 70 \quad(20 \mathrm{~min}), \quad 70 / 30 \quad(30 \mathrm{~min}), 100 / 0$ (35 min); flow-rate, $1 \mathrm{ml} / \mathrm{min}$; detecting wavelength, 200 $400 \mathrm{~nm}$; injection volume: $20 \mu \mathrm{l}$.

Animals Male rats (Wistar strain, weighing 190-210 g) bred and maintained in our animal house were used for these studies.

Antibody Rabbit polyclonal anti-GLUT-4 antibody was raised against the C-terminal 12-amino acid sequence of rat GLUT-4. This antiserum has been successfully used for immunoblotting at $1: 100$ dilution. Goat anti Rabbit IgG was conjugated to HRP.

Activity-Guided Fractionation and Isolation The dried leaves of $C$. sinensis $(600 \mathrm{~g})$ were blended and extracted with $80 \%$ ethanol $(61 \times 3)$ until exhaustion. The liquid extracts were removed of solvent in vacuo to afford a residue ( $149 \mathrm{~g}$ ), which was re-suspended in $\mathrm{H}_{2} \mathrm{O}(61)$. The $\mathrm{H}_{2} \mathrm{O}$ phase was filtered and the filtrate was divided into two portions (3 1 each). One portion was evaporated to dryness under reduced pressure to afford a residue (FA, $66 \mathrm{~g}$ ). The other portion was loaded onto a column containing AB-8 resin $(1.2 \mathrm{~kg})$, and then eluted sequentially with $\mathrm{H}_{2} \mathrm{O}, 70 \%$ and $95 \%$ aqueous solution of EtOH (31 each). The fractions eluted from $\mathrm{H}_{2} \mathrm{O}$ (FB), 70\% (FC), 95\% (FD) aqueous solution of EtOH were evaporated to dryness under reduced pressure using a rotary evaporator, affording 36, 24, and $3 \mathrm{~g}$, respectively. FC was found to be the most active fraction. One portion of $\mathrm{FC}$ ( $12 \mathrm{~g})$ was further separated on a silica gel column chromatography $(200-300$ mesh, $1.0 \mathrm{~kg})$ with a gradient system of $\mathrm{CHCl}_{3} / \mathrm{MeOH} / \mathrm{H}_{2} \mathrm{O}(80: 20: 0 \rightarrow 65: 35: 1)$ as elute to afford compound 1 (550 mg), compound 2 (950 mg) and compound $3(1.1 \mathrm{~g})$.

Induction of Experimental Diabetes Mellitus The overnight fasted rats were made diabetic with STZ (Sigma, St. Louis, MO, U.S.A., $48 \mathrm{mg} / \mathrm{kg}$, i.p). The STZ was freshly dissolved in citrate buffer $(0.1 \mathrm{M}, \mathrm{pH} 3.9)$ and maintained on ice prior to use; the injection volume was $1 \mathrm{ml} / \mathrm{kg}$. Diabetes was confirmed in the STZ-treated rats by measuring the fasting blood glucose concentration $4 \mathrm{~d}$ after injecting STZ. The rats with blood glucose level above $18 \mathrm{mmol} / 1$ were considered to be diabetic and were used in the experiment. Animals had free access to food and water after the STZ injection.

Experimental Groups The diabetic animals were classified into six groups $(1-6)$ each consisting of 6 rats. Group 1 as the diabetic control received $1.5 \mathrm{ml}$ of $0.5 \% \mathrm{CMC}$-solution (vehicle), the rats of group 2 were given the standard oral hypoglycemic agent Metformin hydrochloride (MH) $(1 \mathrm{~g} / \mathrm{kg}$ bodyweight (bw)) in the same vehicle, while groups 3, 4, 5, 6 received FA $(1.26 \mathrm{~g} / \mathrm{kg}$ bw), FB $(0.72 \mathrm{~g} / \mathrm{kg}$ bw $), \mathrm{FC}(0.48$ $\mathrm{g} / \mathrm{kg} \mathrm{bw}), \mathrm{FD}(0.06 \mathrm{~g} / \mathrm{kg}$ bw), respectively. The doses of FA, FB, FC, FD were determined by the yield, and they were from identical amounts of plant. The extracts were redissolved in $1.5 \mathrm{ml}$ of $0.5 \%$ CMC-solution and administered orally by a cannula. Besides the above groups, there was one group as normal control including 6 normal rats.

Collection of Blood and Determination of Blood Glucose Blood samples for glucose determination were taken from the tail vein of $12 \mathrm{~h}$ fasted rats on days 10 and 17 of the experiments. The samples were allowed to clot for $30 \mathrm{~min}$ and the serum was separated by centrifugation.
Serum glucose levels were estimated using the glucoseoxidase-peroxidase method with optical density measured by visible spectrophotometer at $515 \mathrm{~nm}$ and calculated with respect to the standard calibration curve.

Intakes of Food and Water Food and water intakes were recorded daily during the experimental period $(17 \mathrm{~d})$. Average daily intake was calculated for each animal in different groups.

Cell Preparation Adipocytes were isolated from epididymal fat pads from Kun-Ming mice $(30 \pm 5 \mathrm{~g})$ by the modified method of Rodbell, ${ }^{13)}$ Gliemann $^{14)}$ and Marshall et al. ${ }^{15)}$ Following dissection the fat pads were minced and incubated in KRBH-buffer containing $25 \mathrm{~mm}$ HEPES, $200 \mathrm{~nm}$ adenosine, $1 \%(\mathrm{w} / \mathrm{v}) \mathrm{BSA} ; 1.5 \mathrm{mg} / \mathrm{ml}$ collagenase was added and incubation continued for $1 \mathrm{~h}$ at $37^{\circ} \mathrm{C}$. The cells were filtered through nylon screen and centrifuged $(1200 \times \boldsymbol{g}, 1 \mathrm{~min})$. The pellet was discarded and the supernatant was saved. The cell suspension was incubated at $37^{\circ} \mathrm{C}$ for $40 \mathrm{~min}$ with addition of vehicle control (DMSO) or various samples of insulin $(1,10,100,200 \mathrm{~nm})$, Glipizide (1, $10 \mathrm{~nm})$, Methylamine $(10,100 \mathrm{~nm})$, FC $(0.1,1,10 \mathrm{mg} / \mathrm{ml})$, apigenin $(0.01,0.1$, $2 \mathrm{mg} / \mathrm{ml})$, and apigenin-5- $O$ - $[\alpha$-L-rhamnopyranosyl- $(1 \rightarrow 4)$ $6-O$ - $\beta$-D-acetylglucopyranoside $](0.01,0.1,2 \mathrm{mg} / \mathrm{ml})$.

Membrane Preparation The adipocyte membranes were prepared as described previously. ${ }^{16,17)}$ Briefly, the cell suspensions fell into pieces in ultrasonic at $4{ }^{\circ} \mathrm{C}$, and were centrifuged at $3000 \times \boldsymbol{g}$ for $15 \mathrm{~min}$. Fat cakes were discarded, and the supernatant, a fat-free extract, was centrifuged at $12000 \times \mathbf{g}$ for $25 \mathrm{~min}$. The pellet was resuspended as membrane fraction in Medium I (10 mm Tris-HCl, $1 \mathrm{~mm}$ EDTA, $250 \mathrm{~mm}$ sucrose, $\mathrm{pH} 7.4$ ).

Determination of Translocation of the Insulin-Regulated Glucose Transporter GLUT-4 GLUT-4 content was assessed in Western blots. Briefly, the membrane samples were separated by sodium dodecyl sulfate/polyacrylamide gel electrophoresis (SDS/PAGE) (10\% acrylamide gel) (80 and $120 \mathrm{~V}$ during the stacking and separation gels, respectively). Protein was transferred to nitrocellulose (NC) membranes using a Trans-Blot system $(4 \mathrm{~h}$ at $15 \mathrm{~V}$ in $25 \mathrm{mmol} / \mathrm{l}$ Tris, $190 \mathrm{mmol} / 1$ glycine, and $20 \% \mathrm{MeOH}$ ). Following transfer, the membrane was washed with phosphate-buffered saline (PBS) and blocked overnight $(12 \mathrm{~h})$ at $4{ }^{\circ} \mathrm{C}$ with $5 \%$ (w/v) skim milk powder in PBS/Tween 20 (0.1\% by vol.). Blots were then incubated for $2 \mathrm{~h}$ at $37^{\circ} \mathrm{C}$ with an immunoglobulin $\mathrm{G}(\mathrm{IgG})$ monocolonal rabbit anti-rat antibody $(1: 100)$ in $5 \%(\mathrm{w} / \mathrm{v})$ skim milk powder dissolved in PBS/Tween 20 to bind GLUT-4. After the removal of primary antibody, the blots were extensively washed with PBS/Tween 20 thrice, each $10 \mathrm{~min}$. Blots were then incubated for $1 \mathrm{~h}$ at $37^{\circ} \mathrm{C}$ with the appropriate peroxidase conjugated secondary antibody dilution in 5\% (w/v) skim milk powder dissolved in PBS/Tween 20. Following removal of the secondary antibody, the blot was washed with PBS/Tween 20 thrice, each $10 \mathrm{~min}$ and the blot was developed with the NBT/BCIP chromogenic agent and photographed.

Statistical Analysis The data from the experiments are presented as mean \pm S.D. The level of statistical significance was determined by analysis of variance (ANOVA) followed by Dunnett's $t$-test for multiple comparisons. $p$ values less than $0.05(p<0.05)$ were considered as indicative of significance. 


\section{RESULTS}

Effects on Blood Glucose STZ $(48 \mathrm{mg} / \mathrm{kg})$ administration resulted in a significant elevation of glucose level and the MH $(1 \mathrm{~g} / \mathrm{kg}), \mathrm{FA}(1.26 \mathrm{~g} / \mathrm{kg})$, and FC fraction $(0.48 \mathrm{~g} / \mathrm{kg})$ were able to correct this metabolic aberration significantly $(p<0.001)$. The results of all the fractions tested are presented in Fig. 1. MH $(1 \mathrm{~g} / \mathrm{kg})$, FA $(1.26 \mathrm{~g} / \mathrm{kg})$, and FC $(0.48 \mathrm{~g} / \mathrm{kg})$ showed $53.0 \%, 36.0 \%$ and $39.2 \%$ reduction in blood glucose, respectively, in comparison to the diabetic control after once daily administration for $17 \mathrm{~d}$. The FC fraction showed $48.9 \%$ antidiabetic tendency at $0.48 \mathrm{~g} / \mathrm{kg}$ given orally for $10 \mathrm{~d}$ as compared to the basal blood glucose. Figure 1 also showed that there was a tendency for FC to be more effective than FA, although FC was derived from FA.

Intakes of Food and Water The food and water intakes in control and experimental animals are shown in Table 1; the induction of STZ-diabetes resulted in elevated intake of both. The food and water intakes of $\mathrm{MH}(1 \mathrm{~g} / \mathrm{kg})$, FA $(1.26 \mathrm{~g} / \mathrm{kg})$, and FC $(0.48 \mathrm{~g} / \mathrm{kg})$-treated diabetic rats were reduced significantly $(p<0.001)$ when compared to that of the

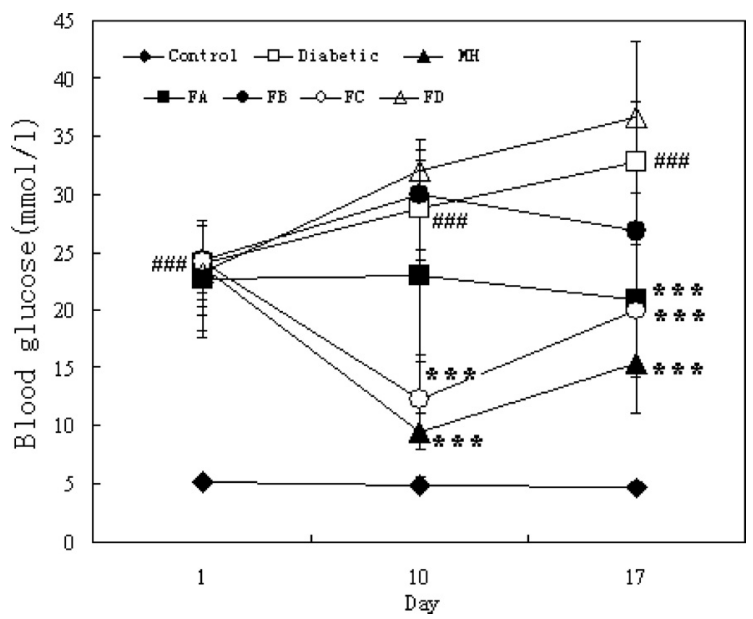

Fig. 1. Effect of Various Fractions of Ethanol Extract from C. sinensis Leaves on Blood Glucose Level in STZ-Induced Diabetic Rats

MH $(1.00 \mathrm{~g} / \mathrm{kg})$, FA $(1.26 \mathrm{~g} / \mathrm{kg}), \mathrm{FB}(0.72 \mathrm{~g} / \mathrm{kg}), \mathrm{FC}(0.48 \mathrm{~g} / \mathrm{kg}), \mathrm{FD}(0.06 \mathrm{~g} / \mathrm{kg})$ were administered orally to the rats for $17 \mathrm{~d}$. The diabetic control rats received the same volume of $0.5 \%$ CMC-solution. Blood samples were taken for glucose determination on days 1,10 and 17 . Values are mean \pm S.D. from 6 rats in each group; diabetic control is compared with normal control; experimental groups are compared with diabetic control; values are statistically significant at $\$ \#<0.001$ as compared with normal control, *** $p<0.001$ as compared with the diabetic control.

Table 1. Effects of Various Fractions of Ethanol Extract from C. sinensis Leaves on Food and Water Intakes in Chronic STZ-Induced Diabetic Rats

\begin{tabular}{lclc}
\hline \hline Group & $\begin{array}{c}\text { Dose } \\
(\mathrm{g} / \mathrm{kg})\end{array}$ & $\begin{array}{c}\text { Food intake } \\
(\mathrm{g} / \mathrm{rat} / \mathrm{d})\end{array}$ & $\begin{array}{c}\text { Water intake } \\
(\mathrm{ml} / \mathrm{rat} / \mathrm{d})\end{array}$ \\
\hline Control & & $28.13 \pm 1.93$ & $32.03 \pm 2.77$ \\
Diabetic & - & $38.53 \pm 4.48^{\# \#}$ & $199.89 \pm 21.93^{\# \#}$ \\
MH & 1.00 & $24.23 \pm 7.67^{* * *}$ & $90.12 \pm 30.32^{* * *}$ \\
FA & 1.26 & $30.99 \pm 4.92^{* * *}$ & $132.89 \pm 12.24^{* * *}$ \\
FB & 0.72 & $38.09 \pm 6.05$ & $221.40 \pm 34.78$ \\
FC & 0.48 & $25.09 \pm 4.93^{* * *}$ & $106.00 \pm 23.89^{* * *}$ \\
FD & 0.06 & $37.20 \pm 5.01$ & $194.08 \pm 30.56$
\end{tabular}

Values are mean \pm S.D. from 6 rats in each group; diabetic control is compared with normal control; experimental groups are compared with diabetic control; values are statistically significant at $\#<0.01$ as compared with normal control, $* * * p<0.001$ as compared with the diabetic control.
$0.5 \% \mathrm{CMC}$-treated diabetic rats.

Structural Elucidation of Compounds The isolated compounds were identified as apigenin-5- $O$ - $[\alpha$-L-rhamnopyranosyl-(1 $\rightarrow 4)-6-O-\beta$-D-acetylglucopyranoside] (1), apigenin (2), apigenin-5- $O$ - $[\alpha$-L-rhamnopyranosyl- $(1 \rightarrow 4)-6-O-\beta$-Dglucopyranoside] (3) by analysis of NMR and MS data, together with comparison of their spectral data with those in the literature. ${ }^{18-20)}$

Compound 1: White crystal (MeOH). ESI-MS: $\mathrm{m} / z 620.9$ $[\mathrm{M}+\mathrm{H}]^{+}, 618.9[\mathrm{M}-\mathrm{H}]^{-}$. UV $\lambda_{\max }(\mathrm{MeOH}) \mathrm{nm}: 262.7$, 332.1. IR (KBr) cm ${ }^{-1}: 3400,1720,1600,1490 .{ }^{1} \mathrm{H}-\mathrm{NMR}$ $\left(400 \mathrm{MHz}, \mathrm{DMSO}-d_{6}\right) \delta: 10.76(1 \mathrm{H}, \mathrm{s}, 7-\mathrm{OH}), 10.22(1 \mathrm{H}, \mathrm{s}$, $\left.4^{\prime}-\mathrm{OH}\right), 7.86\left(2 \mathrm{H}, \mathrm{d}, J=8.8, \mathrm{H}-2^{\prime}, 6^{\prime}\right), 6.91(2 \mathrm{H}, \mathrm{d}, J=8.8, \mathrm{H}-$ $\left.3^{\prime}, 5^{\prime}\right), 6.60(1 \mathrm{H}, \mathrm{s}, \mathrm{H}-8), 6.53(1 \mathrm{H}, \mathrm{s}, \mathrm{H}-3), 6.49(1 \mathrm{H}, \mathrm{s}, \mathrm{H}-$ 6), $5.17\left(1 \mathrm{H}, \mathrm{s}, \mathrm{H}-1^{\prime \prime \prime}\right), 5.44\left(1 \mathrm{H}, \mathrm{d}, J=5.7, \mathrm{H}-1^{\prime \prime}\right), 3.10-4.65$ $(10 \mathrm{H}, \mathrm{m}), 1.87\left(3 \mathrm{H}, \mathrm{s}, 66^{\prime \prime}-\mathrm{AcCH}_{3}\right), 1.06(3 \mathrm{H}, \mathrm{m}, 6-\mathrm{H}) .{ }^{13} \mathrm{C}-$ NMR $\left(100 \mathrm{MHz}, \mathrm{DMSO}-d_{6}\right) \delta$ : $162.2(\mathrm{C}-2), 105.8(\mathrm{C}-3)$, 175.6 (C-4), 157.1 (C-5), 99.0 (C-6), 160.2 (C-7), 96.3 (C-8), 158.7(C-9), 107.3 (C-10), $121.3\left(\mathrm{C}-1^{\prime}\right), 127.9\left(\mathrm{C}-2^{\prime}, 6^{\prime}\right)$, $115.8\left(\mathrm{C}-3^{\prime}, 5^{\prime}\right), 160.5\left(\mathrm{C}-4^{\prime}\right), 99.6\left(\mathrm{C}-1^{\prime \prime}\right), 72.2\left(\mathrm{C}-2^{\prime \prime}\right), 76.5$ (C-3"), $76.7\left(\mathrm{C}-4^{\prime \prime}\right), 73.3\left(\mathrm{C}-5^{\prime \prime}\right), 62.9\left(\mathrm{C}-6^{\prime \prime}\right), 97.0\left(\mathrm{C}-1^{\prime \prime \prime}\right)$, 69.8 (C-2"'), 70.5 (C-3"'), 70.3 (C-4"'), 68.6 (C-5"'), 17.9 (C$\left.6^{\prime \prime \prime}\right), 170.1\left(\mathrm{OCOCH}_{3}\right), 20.4\left(\mathrm{OCOCH}_{3}\right)$.

Compound 2: Yellow powder. ESI-MS: $\mathrm{m} / \mathrm{z} 271.4$ $[\mathrm{M}+\mathrm{H}]^{+}$. UV $\lambda_{\max }(\mathrm{MeOH}) \mathrm{nm}: 268.5$, 336.2. IR $(\mathrm{KBr})$ $\mathrm{cm}^{-1}: 3400,1620,1490 .{ }^{1} \mathrm{H}-\mathrm{NMR}\left(400 \mathrm{MHz}\right.$, DMSO- $\left.d_{6}\right) \delta$ : $12.95(1 \mathrm{H}, \mathrm{s}, 5-\mathrm{OH}), 10.80(1 \mathrm{H}, \mathrm{s}, 7-\mathrm{OH}), 10.37\left(1 \mathrm{H}, \mathrm{s}, 4^{\prime}-\right.$ $\mathrm{OH}), 7.91\left(2 \mathrm{H}, \mathrm{d}, J=8.7, \mathrm{H}-2^{\prime}, 6^{\prime}\right), 6.91\left(2 \mathrm{H}, \mathrm{d}, J=8.7, \mathrm{H}-3^{\prime}\right.$, $\left.5^{\prime}\right), 6.77(1 \mathrm{H}, \mathrm{s}, \mathrm{H}-3), 6.48(1 \mathrm{H}, \mathrm{s}, \mathrm{H}-8), 6.18(1 \mathrm{H}, \mathrm{s}, \mathrm{H}-6)$. ${ }^{13} \mathrm{C}-\mathrm{NMR}\left(100 \mathrm{MHz}, \mathrm{DMSO}-d_{6}\right) \delta: 181.7$ (C-4), $165.2(\mathrm{C}-2)$, 163.8 (C-7), 161.6 (C-9), 161.5 (C-4'), 157.5 (C-5), 128.6 (2C, C-2', 6'), $121.3\left(\mathrm{C}-1^{\prime}\right), 116.2\left(2 \mathrm{C}, \mathrm{C}-3^{\prime}, 5^{\prime}\right), 103.5$ (C10), 102.9 (C-3), 99.2 (C-6), 94.3 (C-8).

Compound 3: White crystal (MeOH). ESI-MS: $m / z 579.0$
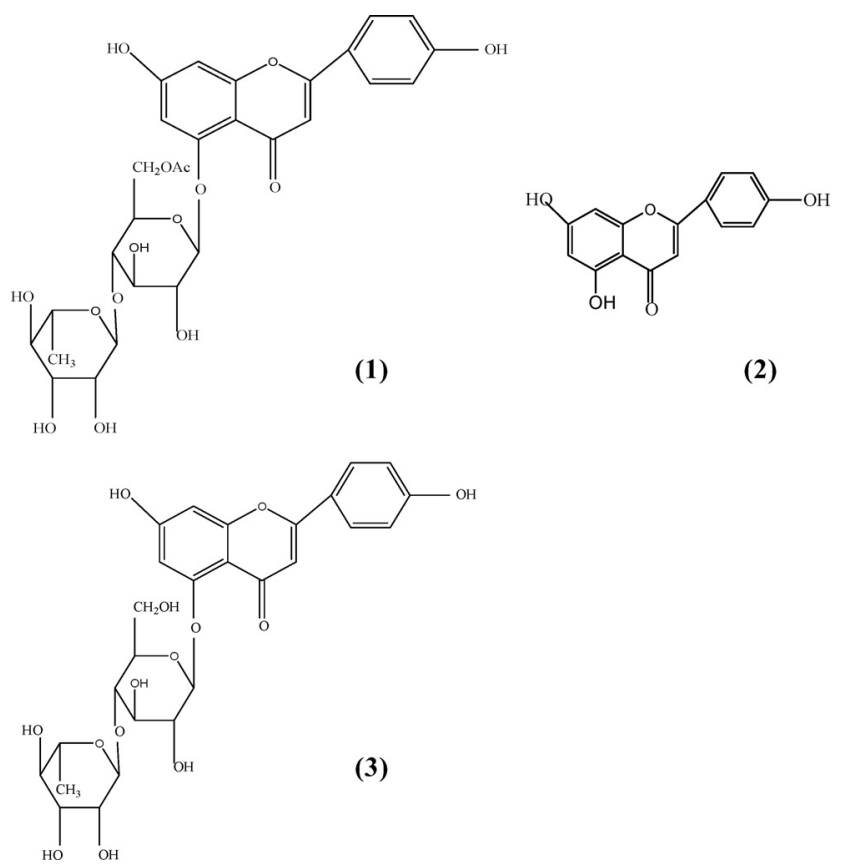

Fig. 2. Structure of Compounds 1, $\mathbf{2}, \mathbf{3}$ Isolated from $C$. sinensis

Apigenin-5- $O$-[ $\alpha$-L-rhamnopyranosyl-( $1 \rightarrow 4)-6-O-\beta$-D-acetylglucopyranoside $] \quad(\mathbf{1})$, apigenin (2), apigenin-5- $O$-[ $\alpha$-L-rhamnopyranosyl-( $1 \rightarrow 4)-6-O-\beta$-D-glucopyranoside] (3). 
$[\mathrm{M}+\mathrm{H}]^{+}, 577.0[\mathrm{M}-\mathrm{H}]^{-} . \mathrm{UV} \lambda_{\max }(\mathrm{MeOH}) \mathrm{nm}: 262.7$, 331.2. IR $(\mathrm{KBr}) \quad \mathrm{cm}^{-1}: \quad 3400,1610,1490 .{ }^{1} \mathrm{H}-\mathrm{NMR}$ $\left(400 \mathrm{MHz}, \mathrm{DMSO}-d_{6}\right) \delta: 10.76(1 \mathrm{H}, \mathrm{s}, 7-\mathrm{OH}), 10.21(1 \mathrm{H}, \mathrm{s}$, $\left.4^{\prime}-\mathrm{OH}\right), 7.86\left(2 \mathrm{H}, \mathrm{d}, J=8.7, \mathrm{H}-2^{\prime}, 6^{\prime}\right), 6.91(2 \mathrm{H}, \mathrm{d}, J=8.7, \mathrm{H}-$ $\left.3^{\prime}, 5^{\prime}\right), 6.60(1 \mathrm{H}, \mathrm{s}, \mathrm{H}-8), 6.52(1 \mathrm{H}, \mathrm{s}, \mathrm{H}-3), 6.50(1 \mathrm{H}, \mathrm{s}, \mathrm{H}-$ 6), $5.19\left(1 \mathrm{H}, \mathrm{s}, \mathrm{H}-1^{\prime \prime \prime}\right), 5.24\left(1 \mathrm{H}, \mathrm{d}, J=5.9, \mathrm{H}-1^{\prime \prime}\right), 3.10-4.96$ $(10 \mathrm{H}, \mathrm{m}), 1.17\left(3 \mathrm{H}, \mathrm{d}, J=6,6{ }^{\prime \prime \prime}-\mathrm{H}\right) .{ }^{13} \mathrm{C}-\mathrm{NMR}(100 \mathrm{MHz}$, DMSO-d $d_{6} \delta: 161.9(\mathrm{C}-2), 105.8$ (C-3), 175.2 (C-4), 157.1 (C-5), 99.2 (C-6), 161.2 (C-7), 96.3 (C-8), 158.7 (C-9), 107.3 (C-10), $121.4\left(\mathrm{C}-1^{\prime}\right), 127.9\left(\mathrm{C}-2^{\prime}, 6^{\prime}\right), 115.8\left(\mathrm{C}-3^{\prime}, 5^{\prime}\right), 160.5$ $\left(\mathrm{C}-4^{\prime}\right), 99.4\left(\mathrm{C}-1^{\prime \prime}\right), 72.2$ (C-2"), $76.5\left(\mathrm{C}-3^{\prime \prime}\right), 76.1$ (C-4"), $73.7\left(\mathrm{C}-5^{\prime \prime}\right), 61.8\left(\mathrm{C}-6^{\prime \prime}\right), 97.0\left(\mathrm{C}-1^{\prime \prime \prime}\right), 69.8\left(\mathrm{C}-2^{\prime \prime \prime}\right), 70.4(\mathrm{C}-$ $\left.3^{\prime \prime \prime}\right), 70.3$ (C-4"'), 68.5 (C-5"'), 18.4 (C-6"').

Effects on the GLUT-4 Translocation The effects of insulin (1, 10, 100, $200 \mathrm{~nm})$, Glipizide (1, $10 \mathrm{~nm})$, Methylamine $(10,100 \mathrm{~nm}), \mathrm{FC}(0.1,1,10 \mathrm{mg} / \mathrm{ml})$, apigenin $(0.01$, $0.1,2 \mathrm{mg} / \mathrm{ml})$, and apigenin-5- $O$-[ $\alpha$-L-rhamnopyranosyl$(1 \rightarrow 4)-6-O-\beta$-D-acetylglucopyranoside $](0.01,0.1,2 \mathrm{mg} / \mathrm{ml})$ on GLUT-4 translocation were estimated by measuring the relative content of GLUT- 4 of mice adipocyte membrane after adipocytes were pre-incubated with the different sam- ples above (Fig. 3). The significant increase in GLUT-4 protein level in adipose tissue treated with insulin $(10,100$, $200 \mathrm{~nm})$ or Glipizide $(1,10 \mathrm{~nm})$ was observed as compared to control. The GLUT-4 level reached the maximum when pretreated with $100 \mathrm{~nm}$ insulin, and $200 \mathrm{~nm}$ insulin could not increase the GLUT- 4 content than $100 \mathrm{~nm}$ insulin. In contrast, Methylamine (10, $100 \mathrm{~nm})$, Semicarbazide-Sensitive Amine Oxidase (SSAO) substrate, dose-dependently decreased the GLUT-4 protein level in adipose tissue. FC $(0.1,1,10$ $\mathrm{mg} / \mathrm{ml})$, apigenin $(0.1,2 \mathrm{mg} / \mathrm{ml})$ potently increased GLUT-4 protein level in comparison to that of control in a dose-dependent manner. In the tested dose range of $0.1-2 \mathrm{mg} / \mathrm{ml}$, apigenin-5- $O$ - $[\alpha$-L-rhamnopyranosyl- $(1 \rightarrow 4)-6-O-\beta$-D-acetylglucopyranoside] weakly increased GLUT-4 protein level. Densitometric scanning revealed increasing in GLUT-4 translocation by ca. 2.7 - and 1.4 -fold by FC $(10 \mathrm{mg} / \mathrm{ml})$ and apigenin $(2 \mathrm{mg} / \mathrm{ml})$, respectively, as compared with control.

Comparative Analysis of the Components of Various Fractions of the Ethanol Extract and Standardization of FC Fraction The components of various fractions of the ethanol extract were analyzed by the HPLC-DAD. The HPLC
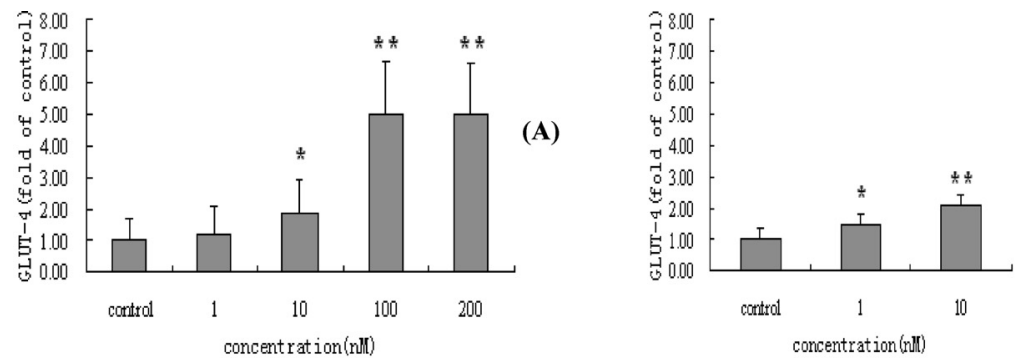

(B)

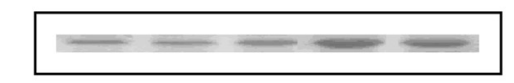

GLUT-4

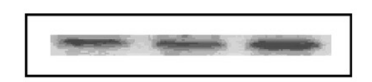

GLUT-4

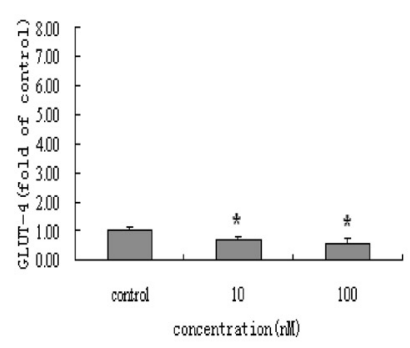

(C)

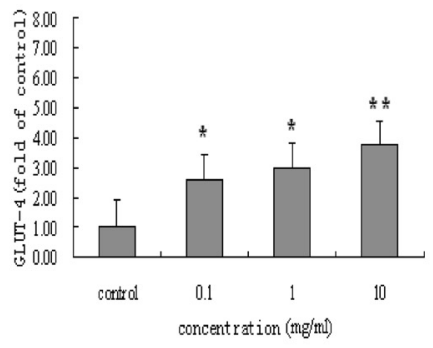

(D)
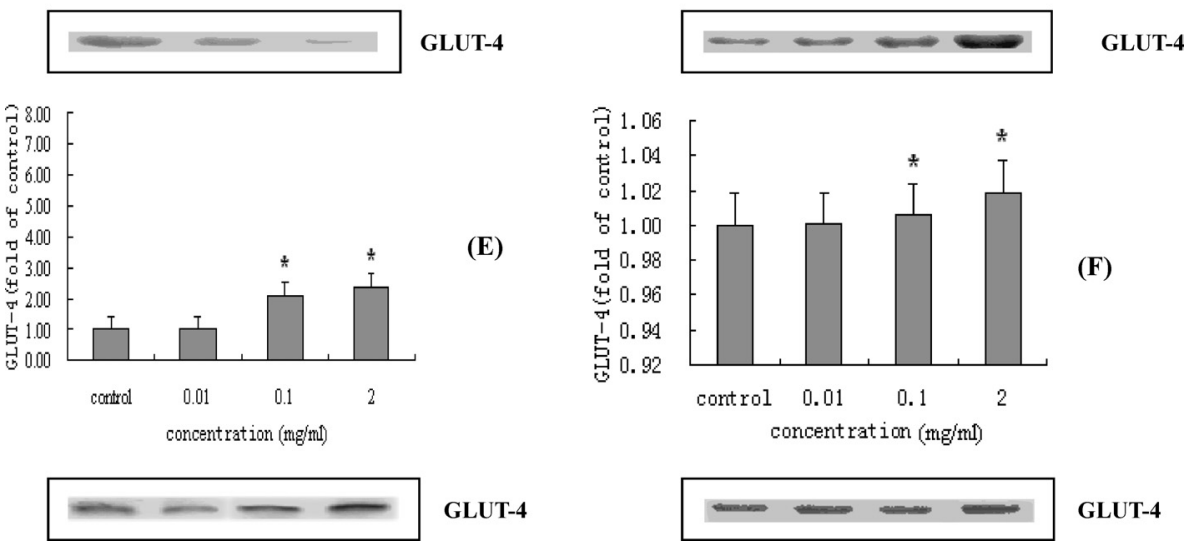

Fig. 3. Effects of Insulin (A), Glipizide (B), Methylamine (C), FC (D), Apigenin (E), Apigenin-5-O-[ $\alpha$-L-rhamnopyranosyl-(1 $\rightarrow 4)-6-O-\beta$-D-acetylglucopyranoside] (F) on GLUT-4 Translocation $(n=3)$.

Densitometric quantifications and representative Western blots are shown. Value represents mean \pm S.D. $* p<0.05 v s$. control, $* * p<0.01 v s$. control. 
chromatograms are shown in Fig. 4. The results showed that the FA was well divided into three fractions, namely FB, FC, FD, respectively.

The active components in the $\mathrm{FC}$ fraction were investigated. This fraction was selected because it showed the strongest antihyperglycemic tendency. The major peaks (111) in the HPLC chromatogram of FC exhibited characteristic UV maximum absorbance of flavonoids, namely, two maximum absorbance bands: band I (300-400 nm), band II $(220-280 \mathrm{~nm})$ (Fig. 5A). The three flavonoid constituents (compounds 1, 2, 3) were detected. Their retention times were $23.7,29.2$ and $10.7 \mathrm{~min}$, respectively, detected by UV monitoring at $254 \mathrm{~nm}$ (Fig. 5A). In the HPLC chromatogram, Peaks $1,9,11$ corresponded to apigenin-5-O-[ $\alpha$-L-rhamno-
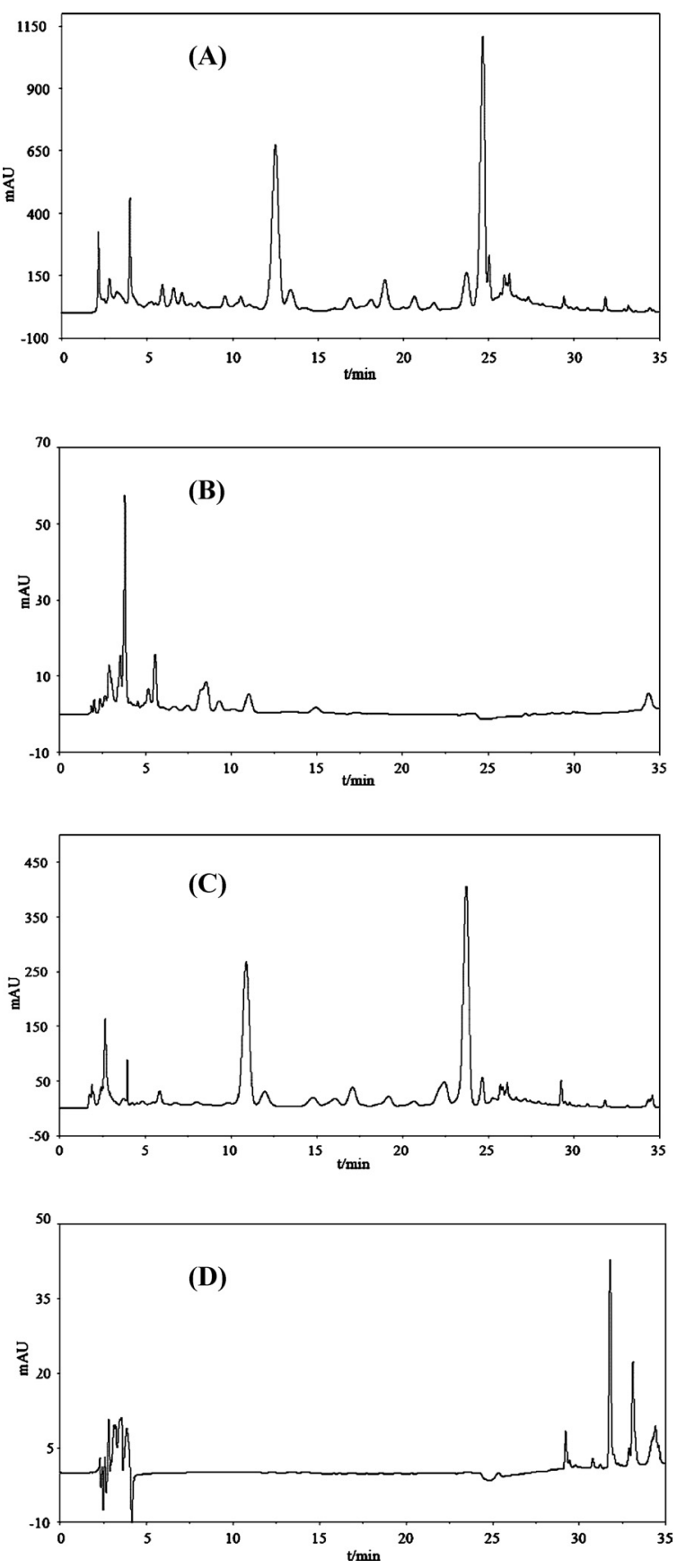

Fig. 4. HPLC Analysis of Various Fractions FA (A), FB (B), FC (C), FD (D) of the Ethanol Extract at $254 \mathrm{~nm}$ pyranosyl-( $1 \rightarrow 4)-6-O-\beta$-D-glucopyranoside] (compound 3 ), apigenin-5- $O$ - $[\alpha$-L-rhamnopyranosyl- $(1 \rightarrow 4)-6-O-\beta$-D-acetylglucopyranoside] (compound 1) and apigenin (compound 2), respectively (Fig. 5). Phytochemical investigation and HPLCDAD analysis indicated that the major principles contained in the fraction FC were flavonoids.

\section{DISCUSSION}

STZ is a diabetogenic agent ${ }^{21)}$ and $\beta$ cell cytotoxic, and it can be used to induce experimental diabetes in rodents. ${ }^{22}$ The results of the present study indicated that $C$. sinensis leaves were an effective herb against chronic STZ-induced diabetes and also in preventing the gain of food and drink intake induced as a consequence of diabetes. The possible mechanism by which FC brings about its antihyperglycemic effect may be potentiation of the insulin effect of plasma.

T2D, which may be caused by the metabolic syndrome, is characterized by a reduced sensitivity to insulin signaling and a reduced efficiency of glucose transport, primarily in adipocytes and muscle cells, leading to hyperglycemia and hyperinsulinemia. ${ }^{23)}$ Glucose transport, which is the first step in glucose utilization, has been found to be a rate-limiting step in glucose metabolism in ruminants as in non-ruminants, and to be regulated by insulin. ${ }^{24,25)}$ Glucose transport across the plasma membrane is carried out by five facilitative glucose transporter proteins in both monogastrics and ruminants: the insulin-sensitive (GLUT-4), which are mainly expressed in adipose tissue and skeletal muscles, and the noninsulin sensitive glucose transporters (GLUT-1, 2, 3, 5). ${ }^{26)} \mathrm{In}-$ sulin resistance in T2D is manifested by decreased insulin stimulated glucose transport and metabolism in adipocytes and skeletal muscle resulting in down-regulation of the major insulin-responsive glucose transporter, GLUT-4. ${ }^{27)}$ GLUT-4 is translocated to the cell membrane to form glucose transport channels after being activated. ${ }^{28,29)}$ This increase in GLUT-4 translocation is compatible with the increased glucose uptake. GLUT-4 in rat adipocytes resides mostly in intracellular sites in the basal state, while cellular insulin treatment caused GLUT- 4 redistribution, leading to a drastic increase in the plasma membrane GLUT-4 level. ${ }^{30,31)}$ GLUT-4 is also shown to be expressed in human skeletal muscle by cloning and characterization of insulin responsive glucose transporters. ${ }^{32)}$ Compounds that activate the insulin-mediated glucose transport signaling pathway can be potentially beneficial for the treatment of metabolic syndrome and diabetes, ${ }^{33)}$ especially for T2D.

A simple and efficient experimental method by simulation of the above study in adipocytic cell following the modified previous method was developed in our lab, which could help us to better screen the active constituents. Our observations revealed activated GLUT-4 translocation by insulin. Glipizide, an anti-T2D drug, also showed the positive result. In contrast, Methylamine (10, $100 \mathrm{~nm})$, SSAO substrate, which can inhibit the GLUT-4 translocation, dose-dependently decreased the GLUT-4 protein level in adipose tissue. Moreover, in our study we found that the FC $(0.1,1,10 \mathrm{mg} / \mathrm{ml})$, apigenin $(0.1,2 \mathrm{mg} / \mathrm{ml})$ could significantly facilitate the GLUT-4 translocation. In the tested dose range of $0.1-$ $2 \mathrm{mg} / \mathrm{ml}$, apigenin-5- $O$-[ $\alpha$-L-rhamnopyranosyl-( $1 \rightarrow 4)-6-O$ $\beta$-D-acetylglucopyranoside] weakly facilitated the GLUT-4 


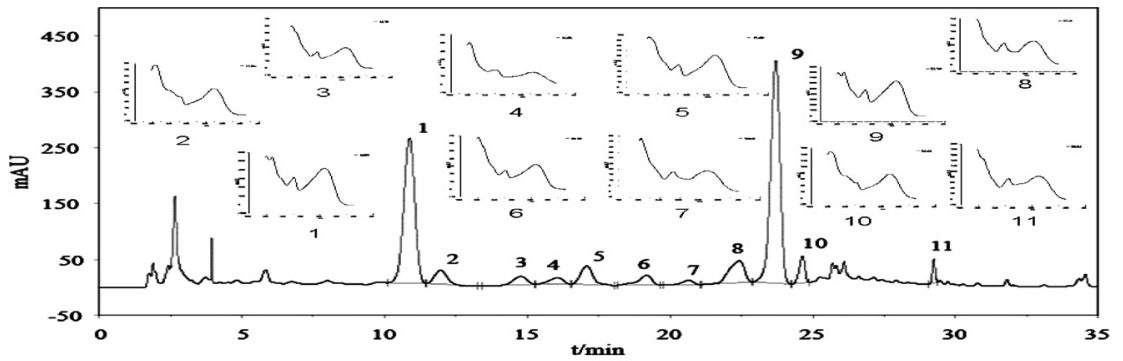

(A)

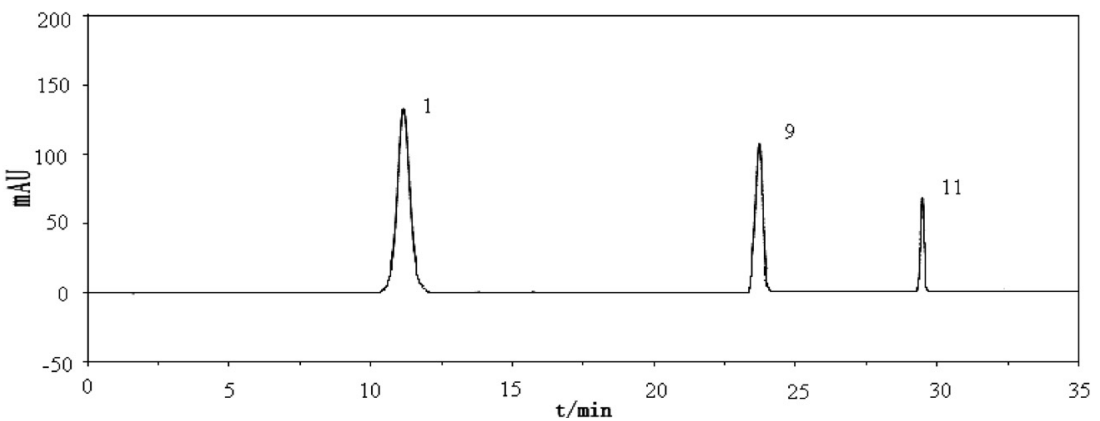

(B)

Fig. 5. The Spectrum of Major Peaks (1-11) in HPLC Chromatogram of FC (A) and HPLC Chromatogram of Standard Compounds 1, 2, 3 (B)

translocation. It was expected that the extract and its flavonoid constituents possessed the effects like the two positive controls (insulin, Glipizide). These results revealed that the flavonoids from $C$. sinensis were the active constituents.

The macropore absorbance resin affords a good separation method for plant extracts. The AB- 8 resin is weak polar. The fractions of $\mathrm{FB}, \mathrm{FC}, \mathrm{FD}$ separated by $\mathrm{AB}-8$ resin represented the polar, medium polar, and less polar components, respectively. The medium polar components corresponding to FC could significantly lower the blood glucose level in STZ-induced rats. Moreover, this fraction had more pronounced antihyperglycemic tendency than the ethanol extract (FA). These showed that the AB- 8 resin could effectively concentrate the active components.

Our phytochemical investigation and HPLC-DAD analysis of FC indicated that the flavonoids were the major principles in the fraction.

Flavonoids are naturally occurring phenolic compounds that are widely distributed in plants. Due to the presence of aromatic hydroxyl groups, flavonoids have strong antioxidant properties. They are scavengers of reactive oxygen and nitrogen species and, therefore, inhibit peroxidation reactions. They also protect macrophages from oxidative stress by keeping glutathione in its reduced form. ${ }^{34,35)}$ Antioxidants can inhibit oxidative glycation (glycoxidation) of tissue proteins with reducing sugars. ${ }^{36)}$ Increased advanced glycation end-product formation has been implicated as one of main molecular mechanisms of how hyperglycemia causes diabetic complications. ${ }^{37)}$ The antioxidant properties are thus associated with DM or its complications.

Flavonoids and their derivatives are active inhibitors to aldose reductase, such as quercetin, silymarin, puerarin, baicalim, berberine, apigenin and so on. The aldose reductase inhibitors can effectively prevent and delay diabetic complications, such as diabetic nephropathy, vasculopathy, retinopathy, and peripheral neuropathy. ${ }^{38,39)}$ Matsuda et al. reported that the inhibitory effect of apigenin on aldose reduc- tase, and the $\mathrm{IC}_{50}$ (concentration of $50 \%$ inhibitory percentage) value was $0.58 \mathrm{~mm}^{40)}$

In the FC, many flavonoids were found involving apigenin, apigenin glycoside. It could be concluded that these flavonoids correlated with the antihyperglycemic activity of FC, although we couldn't exclude the effect of other minor substances.

In conclusion, the fraction from $C$. sinensis leaves extract showed a potent antihyperglycemic effect on chronic STZ-induced diabetic rats, and administration of the fraction did not change the blood glucose levels in normal rats (data not shown). There was no case showing acute hypoglycemic conditions during the administration of the fraction. The flavonoids from $C$. sinensis were the active constituents. The activity of facilitating GLUT-4 translocation of the flavonoids was first found. These results show that the fraction from $C$. sinensis leaves extract is a promising drug for the treatment of diabetes, and the flavonoids may be leading compounds for further study as new drugs for the prevention and/or treatment of DM and its complications.

\section{REFERENCES}

1) Watkins P. J., Brit. Med. J. (Middle East), 10, $82-84$ (2003).

2) Grover J. K., Yadav S., Vats V., J. Ethnopharmacol., 81, 81-100 (2002).

3) WHO, The WHO Expert Committee on Diabetes Mellitus, Technical Report Series, WHO, Geneva, 1980.

4) Hollenbeck C., Reaven G. M., J. Clin. Endocrinol. Metab., 64, 1169 1173 (1987).

5) Ziel F. H., Venkatesan N., Davidson M. B., Diabetes, 37, 885-890 (1988).

6) Berger J., Biswas C., Vicario P. P., Strout H. V., Saperstein R., Pilch P. F., Nature (London), 340, 70-72 (1989).

7) Sivitz W. I., Desautel S. L., Kayano T., Bell G. I., Pessin J. E., Nature (London), 340, 72-74 (1989).

8) Editorial Board of Zhonghua Bencao, "Zhonghua Bencao," Shanghai Scientific and Technical Press, Shanghai, 1999, pp. 341-342.

9) Kuo Y. H., Hwang S. Y., Yang K. L. M., Lee Y. L., Li S. Y., Shen Y. C., Chem. Pharm. Bull., 50, 1607-1608 (2002). 
10) Wang L. W., Su H. J., Yang S. Z., Won S. J., Lin C. N., J. Nat. Prod., 67, 1182-1185 (2004).

11) Politi M., Braca A., De Tommasi N., Morelli I., Manunta A., Battinelli L., Mazzanti G., Planta Med., 69, 468-470 (2003).

12) Lee M. K., Lim S. W., Yang H., Sung S. H., Lee H. S., Park M. J., Kim Y. C., Bioorg. Med. Chem. Lett., 16, 2850-2854 (2006).

13) Rodbell M., J. Biol. Chem., 239, 375-380 (1964).

14) Gliemann J., Diabetes, 14, 643 - 649 (1965).

15) Marshall S., Garvey W. T., Geller M., J. Biol. Chem., 259, 6376-6384 (1984).

16) Machado U. F., Shimizu Y., Lavau M., Horm. Metab. Res., 25, 462465 (1993).

17) McKeel D. W., Jarett L., J. Cell Biol., 44, 417-432 (1970).

18) Wang Y., Chen S. B., Ni J., Yao X., Ye W.-C., Zhao S.-X., J. China Pharmaceut. Univ., 34, 407-409 (2003).

19) Cheng G. R., Jin J. L., Wen Y.-X., Acta Pharmaceutica Sinica, 22, 203-207 (1987).

20) Li S. J., Zhao Y. Y., Wang B., Acta Pharmaceutica Sinica, 31, 849854 (1996).

21) Dulin W. E., Wyse B. B., Diabetes, 16, 512-513 (1969).

22) Rerup C. C., Pharmacol. Rev., 22, 485-518 (1970).

23) Kahn B. B., Flier J. S., J. Clin. Invest., 106, 473-481 (2000).

24) Debras E., Grizard J., Aina E., Tesseraud S., Champredon C., Arnal M., Am. J. Physiol., 256, 295-302 (1989).

25) Hocquette J. F., Bornes F., Balage M., Ferré P., Grizard J., Vermorel M., Biochem. J., 305, 465-470 (1995).
26) Hocquette J. F., Balage M., Ferré P., Proc. Nutr. Soc., 55, 221-236 (1996).

27) Kellerer M., Lammers R., Haring H. U., Exp. Clin. Endocr. Diab., 107, 97-106 (1999).

28) Saltiel A. R., Kahn C. R., Nature (London), 414, 799—806 (2001).

29) Saltiel A. R., Pessin J. E., Trends Cell Biol., 12, 65-71 (2002).

30) Cushman S. W., Wardzala L. J., J. Biol. Chem., 255, 4758-4762 (1980).

31) Suzuki K., Kono T., Proc. Natl. Acad. Sci. U.S.A., 77, 2542-2545 (1980).

32) Fukumoto H., Kayano T., Buse J. B., Edwards Y., Pilch P. F., Bell G. I., Seino S., J. Biol. Chem., 264, 7776-7779 (1989).

33) Li Y. H., Kim J. Y., Li J., Liu F., Liu X. Q., Himmeldirk K., Ren Y. L., Wagner T. E., Chen X. Z., Biochem. Biophys. Res. Commun., 336, $430-437$ (2005).

34) du Thie G., Crozier A., Curr. Opin. Clin. Nutr. Metab., 3, 447-451 (2000).

35) Fuhrman B., Aviram M., Curr. Opin. Lipidol., 12, 41- 48 (2001).

36) Yamaguchi F., Ariga T., Yoshimura Y., Nakazawa H., J. Agric. Food. Chem., 48, 180-185 (2000).

37) Brownlee M., Nature (London), 414, 813-820 (2001).

38) Kador P. F., Med. Res. Rev., 8, 325-352 (1998).

39) Miyamoto S., Expert. Opin. Ther. Patents, 12, 621-631 (2002).

40) Matsuda H., Cai H., Kubo M., Tosa H., Iinuma M., Biol. Pharm. Bull., 18, 463-466 (1995). 